\title{
"Tourism a Tool for Poverty Alleviation in Rwanda: Case of Kinigi Sector of Musanze District"
}

\author{
Dr. Isaboke Peter Kennedy Nyataya
}

$\mathrm{PhD}$ (Sociology-Senior Lecturer),Director of academic Affairs and Quality Assurance, University of Tourim, Technology and Business Studies, Gisenyi Campus-Rwanda

\begin{abstract}
Whereas there are several initiatives to combat poverty in the developing countries, it has been observed that tourism may be, for developing countries like Rwanda, one of the most viable options for advancing their economic and social development. However, there are still unexplored scientific arguments to support the real impacts of these programmes at various levels. The present research attempted to contribute to fill this gap in the scientific literature about tourism and poverty alleviation. Its essential theoretical implication was to identify the main determinants that support the wide concept of capacity building and its role in triggering poverty reduction through tourism.
\end{abstract}

During the study, a non-probabilistic sample of seventy (70) respondents was used. Thus, primary data was collected from local people of Kinigi Sector of Musanze District. The main research instruments used were directed questionnaires and documentation. Primary data collected were first entered in SPSS and then analysed using its descriptive tools.

The study revealed that, tourism related activities have helped the local people to get jobs and create small scale projects, hence contributing towards the reduction of poverty in the area. Besides, it was observed that tourism has helped the local people to get markets for their agricultural and handcraft products. Based on elementary poverty indicators, the study has shown that general living conditions of rural people has improved because of tourism. Based on the scope and delimitation of the study, some recommendations were provided.

Keywords: Tourism, Tool, Poverty Alleviation, Rural People, Development

\section{INTRODUCTION}

Tourism has been and continues to be one of the key channels for alleviating poverty in developing countries, Rwanda inclusive. Though tourism growth is not universally inclusive of the poor, our understanding of how tourism affects the poor is largely based on partial and superficial analysis. It has been observed that Tourism can not only lead to the socio economic development of a country but also help in reducing poverty of a population in a given area.

The diversity and seasonal nature of tourism demand mean that most of an area's players can offer specific products liable to interest a customer segment, which, however small, can form a source of extra income and an important catalyst locally.

As composite economy of five major human activities manufacturing, crafts, agriculture, transport and services, tourism generates a wide range of jobs from highly skilled and unskilled, to start-up opportunities for a good number of small and medium enterprises.

Tourism promotes and creates economic assets for cultural and natural heritage, contributes to the protection and conservation of natural resources, builds awareness of and a responsible approach to these issues. Besides, it serves as a major source of Rwanda's revenue and plays a key role in alleviating poverty among the general populations as well.

\section{BACKGROUND OF THE STUDY}

Pro-poor tourism, coined in the late 1990s, is an appropriate strategy if adopted that can alleviate poverty. It emerged through the confluence of two conceptual developments, alternative tourism and, the discourse and practices of development. As globalisation has been pushing societies toward borderless world, international tourism has been growing rapidly, too. 
As globalisation accelerates, freer movements of capital and people through the removal of various institutional barriers, international tourism has also continued to grow in recent past. In 1970s, the number of international tourist arrivals was 165 million people in worldwide. In terms of international tourism receipts, it was 18 billion U.S. dollars. In 1993 when European Union was formed, the number of international tourist arrivals increased to 519 million people and the receipts amounted to 324 billion U.S. dollars (Takadera 2004: 12).

In 2008, 924 million tourists travelled abroad, marking more than 100,000 arrivals in every hour. Three-quarters of these journeys started in high or upper-middle income countries. Remarkably 40 per cent of these journeys ended in a developing country, Rwanda inclusive. International tourists are significantly better than development agencies at spending money in poor countries. In 2007, tourists spent US\$295 billion in developing countries almost three times the level of official development assistance. Hence, it is for this reason that tourism has been described as the world's largest voluntary transfer of resources from rich people to poor people, (Ashley and Mitchell, 2012).

Rwandan Government and other national governments in developing countries have recent and explicit policy statements asserting the role of tourism as strategy for reduction of poverty. About 80 per cent of African Poverty Reduction Strategy Papers include a reference to encouraging tourism (Gerosa, 2003). Although tourism advocates often leap on this as evidence that African governments understand the potentially positive role of tourism, the priority afforded to tourism in important policy documents is very much less than more traditional preoccupations with agriculture, rural development and infrastructure. At local level a good number of local governments, non-governmental organisations (NGOs) and civil society organisations embrace tourism as tool to facilitate local economic development. However, the empirical basis for making policy choices or recommendations often appears thin.

There are others who view the pro-poor potential of tourism as over-stated. Tourism is criticised by some as having high 'leakages', benefiting only a skilled labour 'aristocracy' and representing an unacceptable juxtaposition between the luxury enjoyed by the tourists and the poor living conditions for people situated around the destinations. A number of Western tourism researchers have highlighted the negative cultural and social effects of tourism have on poor local communities and frequently question the supposed economic benefits of trade in tourism services (Broham, 1996)

The World Tourism Organisation (WTO) launched its publication "Tourism and Poverty Alleviation" in Johannesburg in 2002 (WTO, 2002b); published recommendations for action on tourism and poverty alleviation and has launched a Foundation: Sustainable Tourism- Eliminating Poverty (STEP) which is now developing pilot projects in developing countries. Rwanda inclusive. All this is based on the assumption that tourism can be an effective tool for poverty reduction. The WTO called for broad and specific indicators of poverty alleviation resulting from tourism, saying that 'such reporting may be a condition of any assistance given' (WTO, 2004). However, to date, WTO and STEP are not generating the empirical evidence that would either provide the information for their partners to overhaul tourism policy in a pro-poor way, or would substantiate the benefits of specific interventions.

The bulk of the pro-poor tourism literature has not been aimed at measuring impact but on assessing what strategies can help expand impacts on the poor. While there have been practical reasons to focus on promoting interventions, the lack of quantification of impact is indeed recognised as a weakness in the pro-poor tourism literature by its proponents (Ashley et al, 2004) as well as its detractors (Chok and Macbeth, 2007).

Tourism advisers from the Netherlands Development Organisation (SNV), carried out an assessment of government strategies for increasing local economic impacts of tourism in Rwanda, Kenya, Ethiopia, Tanzania and Mozambique. Not only the assessments but also the policy document and strategies they reviewed, are strikingly devoid of empirical evidence concerning impacts of tourism on poor people, bar some headline employment figures, a couple of pieces of data from village projects and the occasional statistic from a World Bank Report as noted by Mtui (2007).

\section{Problem Statement}

Tourism in Rwanda has existed for many decades though not well tapped as it is supposed to be for it yet to positively impact the people who are expected its first beneficiaries, for instance, those 
living around the national parks such as those of Kinigi Sector of Musanze District, who live around the Volcanoes National Park in the North West of Rwanda.

Even though statistics show that tourism is among the best industries that bring in foreign returns (2012-13), the questions that remain are: how does it leave the local people feeling?; Does it bring change to where they live or to their ways of living?; Do they earn anything from it?; How about the Government of Rwanda?; Does it and its partners give back to the local people and their communities so as to change their poverty status? If yes, in which way?

Poverty remains one of the most challenging problems in the developing countries despite the growing tourism sector. The challenge here is how to address this problem with both the local people and communities who are expected to benefit directly from tourism.

It is against this backdrop the present study was conducted in Kinigi Sector of Musanze District with a view to finding out what kind of benefits have the local people gained from tourism in general and how tourism impacted them in terms of creating jobs and poverty reduction in particular.

\section{OBJECTIVES OF THE STUDY}

The present study was guided by both the general objective as well as the specific objectives.

\subsection{General Objective}

The general objective of the study was to understand the place of tourism in the fight against poverty in Kinigi Sector and find out the extent to which the local community has generally benefited from tourism socially and economically.

\subsection{Specific Objectives of the Study}

The specific objectives of the study were:

1. To highlight how tourism has contributed in improving the socioeconomic lives of the people of Kinigi Sector.

2. To identify the problems the local community has faced as the result of tourism and how it has addressed them.

3. To understand the efforts the local community is making towards the promotion of tourism in the area.

4. To analyse the interlinkage between the tourists, local people, Virunga National Park and the Government of Rwanda

5. To find out how the local communities can have more direct benefits from tourism with a view to reducing their poverty level

\subsection{Significance of the Study}

Social Planners, policy makers and administrators at different levels may use the findings of this study to find out how they can improve tourism in the area with a view to reducing poverty amongst members of the community.

Besides, the researcher is of the opinion that the information gathered through study will help the local administrators of Kinigi Sector in particular and Musanze District in general to effectively make use of tourism in the area as tool for sustainable poverty reduction.

The findings of study are also important to the academics and other researchers due to the fact that it could provide material information for references and consultancies by policy makers. Students of tourism shall, too, directly or indirectly benefit from the data collected and the findings of the study.

\subsection{Scope of the Study}

The study was carried out in Kinigi Sector of Musanze District, Northern Province of Rwanda. Emphasis was put on the understanding of the relationship between tourism and socioeconomic situation in general and in particular poverty reduction in Kinigi Sector

\section{LiteratURE REVIEW}

Poverty eradication is the first of the United Nations established Millennium Development Goals (MDGs), with sustainable tourism being recognised as a major development activity to the attainment 
of the said goals. In the recent years, commitment to tourism as a development strategy for the developing world has gained a renewed interest within governments and development organisations in the fulfilment of the United Nations MDGs. However, despite several developing plans, aid projects, grants, loans and structural adjustments, limited progress has been made to achieve the targets defined in that goal (Lima et al., 2011).

It is observed that tourism, which brings individuals and human communities into contact and through them cultures and civilisations, can play an important role in facilitating dialogue among cultures. Besides, tourism has the capacity to help the world's inhabitants to live better together and hence, contributing to the construction of peace of mind of both men and women.

Tourism is defined as, "the activities of people travelling to and staying in places outside their usual environment for no more than one year for leisure, business, and other purposes not related to an activity remunerated from the place visited' (World Bank, 2009: 393).

Often, under the radar of official statistics that will equate 'tourist' with 'foreigner'- is business tourism. A trader from a peripheral town who comes to the capital city to buy goods to take home to sell is a business tourist .However, if he sells any goods in the capital city; he is earning funds from the destination and becomes a migrant worker.

The distinction is subtle and the implications of defining a person as a 'tourist' or a 'migrant' are important.

Poverty is the state of one who lacks a certain amount of material possessions or money. Absolute poverty or destitution refers to the deprivation of basic human needs which commonly includes food, water sanitation, clothing, shelter, health care and education. Relative poverty is defined contextually as economic inequality in the location or society in which people live.

The prevailing literature classifies tourism on the socio-economic effects on the national and regional economy as regards the benefit side, as follows (Pearce, 1991):

- Balance of payments: For many nations, tourism is often the main source of foreign exchange earnings, although some reductions of the net benefits of the balance of payments can be expected because of the actions of foreign tourist operators;

- Regional development: Tourism frequently spreads economic activities more across the internal border of the particular country;

- Diversification of the economy: Because of its multi-faceted nature, tourism may foster the build up of solid economic development;

- Income levels: The income effects of tourism may give rise to wide variations in income multiplier;

- State revenue: The State earns revenues due to tax collections; although it has been acknowledged that significant expenditures for building and construction activities may also be required;

- Employment opportunities: The most countries tourism is an important source of employment, especially for the unskilled and semi-unskilled labour-force.

Poverty is a multidimensional and complex concept that cannot be reduced to a single dimension of human life. Poverty includes inadequate income and human development, but also embraces deprivation of a longer life span, access to safe water, lack of health, acceptable housing, knowledge, creative life, freedom, voice, participation, dignity, self-esteem, power, representation, personal security and respect of others (Zhao and Ritchie, 2007)

Several approaches to international development assistance emerged in the recent decades in which tourism is considered the main tool for poverty alleviation. Nevertheless, a gap is evident in the scientific literature as little emphasis has been given to the impact of tourism on poverty alleviation through international development cooperation programs.

Bearing in mind that the United Nations World Tourism Organisation (UNWTO) is the leading international organisation with a decisive and central role in the world tourism and on the ability to influence national and international development policies, it was considered relevant to analyse its role in the overall discussion around the international cooperation for development in tourism. This is 
even more required since it achieved the status of a UN specialized agency, having tourism since then gained official acknowledgement from the World Bank on its importance for poverty reduction, according to the MDGs. In the last decade, the UNWTO reinforced its efforts to promote sustainable tourism development in order to reduce poverty. It launched several initiatives and programs assuming a leading position to promote tourism as a potential tool for development, in line with the MDGs. This is the case of the Sustainable Tourism for Eliminating Poverty (STEP) and UNWTO. Volunteers programs, yet with different focus. (SNV 2010)

\section{Determinant Factors of Poverty Alleviation through Tourism}

Community participation is essential in development as it results in more suitable decisions (Cole, 2006). As service industry, tourism is highly dependent on the goodwill and cooperation of host communities. (Tosun (2000), further, argues that the local community is more likely to know what will work and what will not in local conditions.

Several developing countries face the problem of ownership and control being confined mainly to foreign chains and large-scale national businesses, particularly, within the hotel industry. This means that only multi-national companies and large-scale national capital reap most of benefits associated with the industry leading to higher leakages (Cole, 2006; Tosun, 2000).

The dimension of ownership should also consider the perspective of the agreements under the "Paris Declaration on Aid Effectiveness" which defends that any project for development cooperation should focus on national ownership where partner countries commit to "exercise leadership in developing and implementing their national development strategies" and donors "respect partner country leadership and help strengthen their capacity to exercise it" (OECD, 2005:14).

Zhao and Ritchie (2007) propose an integrative framework for anti-poverty tourism research, arguing that any development effort or approach, to be justified and successful, should consider three main determinants: opportunity, empowerment and security. Opportunity means the poor ought to have access to economic opportunity of which they can take advantage to change their destiny (Zhao and Ritchie, 2007).

In the context of the development work, empowerment is a key word although it may be while knowledge is a crucial element of empowerment (Tosun 2000), communities need access to a wide range of information. Furthermore, "meaningful participation cannot take place before a community understands what they are to make decisions about" (Cole 2006, p.632). In fact, as pointed out by Ashley et al. (2004), the poor have a weak understanding about tourists as well as the way the tourism industry works, and changing this state of affairs would be very important to make informed and suitable decisions about their own tourism development. A knowledge deficit perpetuates a vicious cycle of economic deprivation and poverty (Nadkarni, 2008). Communication is then a central dimension for capacity building as it is a condition for knowledge sharing that in turn leads to empowerment. In fact, communication lies at the basis of all human development, in any context (Romanow and Bruce, 2006).

Where stakeholder engagement needs to be focused, it is crucial to generate strategic competitive advantage through networks (Cooper, 2006) which, associated with clusters of interests, are preconditions for innovation and community capacity building. Nonetheless, many organisations and stakeholders need to be persuaded that cooperation will enhance their own competitiveness, and thus there is a need for demonstrating the benefits of cooperation across the destination (Cooper, 2006). Networking, clustering and agglomeration theories are increasingly being adopted to explain the role of tourism in influencing local growth and stimulating regional development as reviewed by Novelli et al. (2006).

Promoting tourism per se as a tool for poverty alleviation constitutes a neo-liberal pro-poor approach that neglects the dimension of equity, which may lead to an aggravation of poverty (Schilcher 2007: 167). To be sustainable, the processes of change induced by any development intervention must promote equity between and for, all women and men (Eade, 1997).

The role of the state is crucial. There is a general agreement that "better and more effective states are needed if development is to succeed in the world's poorest countries" (Fritz and Menocal, 2007: 532). Without genuine government intervention the poorest are bound to carry heavy burden in terms of costs of environmental degradation, cultural commodification and social displacement capacity 
building is, therefore, considered in the present study in its wider context, as presented by Partidário and Wilson (2009), who state that it is a concept founded on sound principles of democracy, participation, development and continuous improvement of skills, shared learning processes.

\section{Tourism ANd Poverty Alleviation}

While tourism development is widely recognised for enhancing the quality of life of those societies in the developed world, for many developing nations it has a critical and direct role to play in the alleviation of poverty (Ashley, Roe and Goodwin 2001). This is accepted by all the major international donor agencies such as the World Bank and the IMF, as well as by the World Tourism Organisation (Meyer, 2003). According to the United Nations, some 1.2 billion people have no clean water; over 2 billion have no access to a reliable energy supply and approximately 2.5 billion lack sanitation services.

In poor societies, lacking natural resources and devoid of infrastructure and, basic access to investment, various aspects of culture and traditions are harnessed and developed for touristic purposes. The wealth created by tourism depends to a large extent on subjective and intangible values such as the 'beauty' of natural landscapes and the 'authenticity' and symbolic value of different cultural expressions and traditions (MacCannell, 1976). Poor nations, while lacking in raw materials, or the opportunities to develop them, can nonetheless be extremely wealthy in cultural terms. While it is recognised that tourism on its own is unable to solve the deep rooted structural and cultural problems of long term poverty, it has a vital role to play, particularly when it is linked to other aspects of development.

One of the most commonly cited alternatives to this model is that adopted under the broad heading of ecotourism (also variously referred to as 'sustainable/green/soft' tourism). This type of tourism development model builds upon environmental and ecological resources and is generally based on grass-roots approach with the participation of local communities and stakeholders in the planning process. The eco-tourism model does not relate to some destinations, fails on most occasions to integrate with aspects of cultural heritage and local cultural conditions, and is itself a fragile approach open to appropriation by external tour operators, relying on 'high value' tourists and open to considerable competition (Boo, 1990).

However, in recent years so called 'pro poor tourism' has emerged as an approach to the development and management of tourism. The overall aim is to streamline the flow of benefits brought by tourism directly to those within the community that need it most (World Tourism Organisation 2004).

It enhances the linkages between tourism businesses and poor people so that tourism's contribution to poverty reduction is increased and poor people are able to participate more effectively and directly in product development (Roe \& Urquhart 2002). Links with many different types of 'the poor' need to be considered: staff, neighbouring communities, land-holders, producers of food, fuel and other suppliers, operators of micro tourism businesses, craft-makers, other users of tourism infrastructure (roads, resources water) etc.

There are many types of pro poor tourism strategies, ranging from increasing local employment to building mechanisms for consultation or integrating small businesses to the commercial circuits of the tourism sector. Any type of company can be involved in pro-poor tourism - a small lodge, an urban hotel, a tour operator, an infrastructure developer. The critical factor is not the type of company or the type of tourism, but that an increase in the net benefits that go to poor people can be demonstrated.

\section{RWANDA's TOURISM POLICY}

Tourism has been identified as a priority sector to achieve Rwanda's development goals as set out in Vision 2020. With the application of previous tourism policies, the country has been able to make significant progress in developing and managing its tourism sector in recent years. In 2008, the number of foreign visitors to Rwanda reached just under one million from about 826,000 in 2007, an increase of 30 per cent. Estimates indicate that tourism revenues significantly increased between 2007 and 2008 , from $\$ 138$ million to $\$ 209$ million.

However, this notable development of the sector has necessitated a review of the existing tourism policy as well as the creation of an aligned sustainable tourism master plan. Together these documents aim to bring order to the industry with new legislations and improved coordination, as well as to stimulate investment and increase private sector involvement. 
Rwanda's Tourism Policy (2009:5), specifically, aim to address a number of constraints and issues that face the tourism industry. They include: Over-reliance on a single tourism product ;International awareness and perceptions of Rwanda not widely based on tourism ;Low capacity and under-skilled human resources; Little involvement of communities and micro, small and medium enterprises (MSMEs) in the sector;Expensive and difficult to access from key tourism source markets as a destination; Under-developed regulatory framework for the tourism sector; Constraints due to quality and quantity of infrastructure; Difficulty of accessing land for tourism investments; Little focus on the environment and sustainability and Low availability of finance and partnership for private sector investment in the sector

The overall objective of the Tourism Policy is to increase tourism revenues in a sustainable manner, generate profits for reinvestment and create jobs. The aforesaid will be done through developing new and distinctive and, market-led products that are clearly positioned and promoted in the marketplace, which, will bring about spatial and socio-economic balance to the distribution of tourism benefits. For Rwanda, sustainable development incorporates environmental, social and economic elements.

To sustainably increase tourism in Rwanda the following strategic objectives have been in practice since 2009. They include:

- Product development and Diversification - Development of a range of quality tourism products and services, capable of attracting and meeting the needs of international, regional and domestic visitors.

- Marketing and Awareness - Projecting a clear, distinctive, image of Rwanda as wildlife, ecotourism, cultural and conference destination that is attractive to a high-value market.

- Capacity Building - Developing systematic, high quality training, to create a skilled workforce in value jobs at every level of the tourism and hospitality industry.

- Communities and MSMEs - Providing support to MSMEs, ensuring that they have the capabilities and capacities to enter the tourism value chain, while also ensuring that communities contribute to and benefit from the tourism industry.

- Access to Rwanda as a Destination - Ensuring that international tourists have minimal hassle in their journey to Rwanda in terms of air and land access, as well as in Visa and other requirements.

- Framework of Regulation - Establishing and maintaining regulation that enables the tourism industry to develop in a fast yet sustainable manner.

- Infrastructure Development - Prioritising the provision of infrastructure within the Destination Management Areas (DMAs) and their associated corridors.

- Land - Enabling tourism investments through ensuring the availability and security of land tenure for development.

- Environmental Sustainability - Ensuring that the tourism sector is planned and developed to the benefit of future generations of Rwandans, in terms of the sustainability of resource use, the protection of wildlife and the environment.

- Investment and Financing - Developing incentives and a financial architecture that supports investment in the tourism industry. (Tourism Policy in Rwanda, 2009:5)

- Therefore, it can then be stated that tourism in every way increase the means of creating Jobs and other side opportunities therefore impacting on peoples live hoods and enhance fighting against poverty.

\subsection{Research Design}

Case study design was adopted for the study.

\subsection{Target Population}

The target populations for this study were the people (adults) of Kinigi Sector of Musanze District with a total population of 27,512 (NISR, 2012: 32) of the total of estimated number of 368,563 people in Musanze District 


\subsection{Sample Size and Sampling Procedure}

A purposive random sampling technique was used in identifying the respondents covered under the study.

\subsection{Methods of Data Collection}

The research used question method, interview method and documentary method in collecting the relevant data for the study.

\subsection{Data Analysis}

Data analysis was done with the help of SPSS matrixes and Excel spreadsheets.

\section{Reasons for Selecting the Present Study Area}

The study focused on Kinigi sector in Musanze District. Musanze district is located in the North of the country. Kinigi sector is made up of 5 cells that is Kaguhu, Nyabigoma, Nyonirima, Kampanga ,Bisoke.

The reason as to why the researcher took Kinigi Sector as a case study was simply because it is the place where there is a lot of tourism activities and therefore its where the researcher could get appropriate information and considering the accessibility of the area. It offered that good choice of an area in which to conduct a research study. The case study can be explained well below.

\subsection{Tourism has Transformed Lives in Kinigi Sector and Musanze District}

Kinigi sector in particular and Musanze district in general have benefited from tourism as it is one of the top earners of the district and this has helped them in combating poverty in various ways, for example, Kinigi sector boosts of five hotels of which most are five and three stars grades. These in a way have boosted economic living conditions of the local communities who benefit from the sale of food stuffs used such as potatoes they make to the hotels. This has helped local farmers have regular incomes from the sales and hence uplifted their standards of living.

Virunga National Park, which is the habitat of the famous gorrillas and which generates most of the revenue to the government is located in Kinigi Sector of Musanze District and. The Park has provided jobs to the local people who serve as tour guides, park rangers and other related employments opportunities.

Through this Park, too, a good number of cooperatives has emerged which aim at bringing people together to make handicrafts such as wood curving and paintings which they then sell to tourists as souvenirs. It has been observed that the people in the area have made profits from selling these products and hence, generally, helped in reducing poverty in their households.

Construction of roads is one other product of tourism in the area. For instance, schools have been constructed, roads such as Ruhengeri-Kinigi has been tarmacked to facilitate smooth transportation of tourists to the National Park. Hence,the locals have benefited greatly from this for they now able to transport their agricultural produce easily to the markets.

Establishment of small and medium enterprises such as restaurants and lodges for tourists have been of great importance in providing the local people with the marketfor their agricultural produce and employment opportunities.

Schools have been constructed through the government's initiative of "revenue sharing " in which 5\% of the total revenue from the National Park is injected back to the people improve the community projects in particular and other initiatives in the area, at large.

Different associations and community initiatives have come into being as a result of tourism For example Iby'Iwacu Cultural Village, Conservation Project and Sakola have played a central role in enabling its members to have constant source of income through cultural dancing and other related cultural exhibitions.

\section{TOURiSM AND Poverty Alleviation}

Tourism adds value to common attractions located in the developing countries, besides, the hot and gentle climate, cultural heritage, outstanding landscapes and abundant biodiversity. It serves as strong 
market and labour bidding, consisting of, traditionally, small and medium enterprises. A great deal of jobs, particularly those directed towards the women, youth, disadvantaged groups and minorities in the area have been created through this industry.

Travel and tourism industry which are closely related happen to determine the development of other branches of the downstream and/or its upstream such as agriculture, handicrafts, transport services to mention a few. Participating in tourism activities and therefore, attracting more tourists to areas means more economic exchanges in the area, which to a large extent, determines its economic development. The tourism consumption requires the presence of the same place at the same time of the producer and consumer. The interaction between tourists and poor communities can produce practical and intangible benefits, besides, care for cultural and environmental values.

Certain negative aspects of tourism that are closely related to poverty alleviation require particular consideration so as to provide sufficient sources of income throughout the calendar year are noted below.

\subsection{Life Support Systems Impact on Tourism}

These include water, soil, food, energy and biodiversity. Their accessibility for the poor can threaten the competition created by using the same tourism resources. Degradation of cultural and environmental, for instance, can have sustainable effects to area and its occupants

\subsection{Unpredictability and Fluctuation of Tourist Demand}

Tourism is sensitive to socioeconomic, political and environmental conditions of an area. In the absence of insurance and social security, the poor are vulnerable to such phenomena. Besides, tourism demands drastic change of people's behaviour when circumstances change;

\subsection{Seasonality of Tourism Demand}

This calls for proper integration between tourism and other economic activities. The nature of tourism investment and lack of the poor's 'employment can cause higher costs. Tourism should not be regarded as a response to eliminate poverty but can bring about the expected change directed towards its reduction.

\section{Presentation, ANAlysis ANd InTERPRETAtion}

\subsection{Socio-Economic Characteristics of the Respondents}

The socioeconomic of characteristics of the respondents such as age, sex, marital status, education level, and occupation were considered important for the study for they were assumed to influence the perceptions of the respondents on the role of tourism in reducing poverty in the selected area for the present study.

However, due to time and cost constraints, it was not possible for the researcher to cover all cells of Kinigi Sector in study. Hence, Kaguhu, Bisoke, and Nyabigoma cells were selected.

\subsection{Cell of Respondents}

$32.9 \%$ of the total respondents were selected from Kaguhu cell, $24.3 \%$ from Bisoke Cell and $42.9 \%$ from Nyabigoma cell.

\subsection{Age of Respondents}

It was noted that out of the total of seventy(70) respondents covered in the study, 5.7\% were aged 24 years and below, $57.1 \%$ of them aged between 25 and 34, $21.4 \%$ aged between 35 and 44 years, and only $15.7 \%$ were aged 45 and above. Hence, it can be noted that the majority of the respondents (78.5\%) belong to the age group $25-45$.

\subsection{Sex of Respondents}

The study revealed that the majority $(39 / 70,55.7 \%)$ of the respondents were males whereas females were the minority $(31 / 70,44.3 \%)$.

\subsection{Marital Status of Respondents}

It was observed that $14.3 \%$ the respondents were single, $70 \%$ of them are married and whereas 15.7 $\%$ were either widowed, separated or divorced. 


\subsection{Respondents' Educational Level}

Noted was the fact that $14.3 \%$ of the respondents had no formal education, $74.3 \%$ of them were found to have primary education and only $11.4 \%$ had secondary or tertiary education.

Hence, it was seen that the majority $(74.3 \%)$ of the respondents has primary education. The finding make sense for the majority of people in rural areas, more often than not happen to have limited opportunities of advancing to higher level of education probably due to unfavourable socio-economic conditions.

\subsection{Respondents' Occupation}

The majority $(72.9 \%)$ of the respondents found to be employed in agricultural and agriculture related activities, $10 \%$ of $\mathrm{t}$ hem percent were salaried and whereas $17.1 \%$ were running their own business. To the present researcher this was not a surprising finding for it is commonly observed that the education level, to a large degree, is correlated to someone's occupation.

In this study also, it is evident that many people are found in the primary sector as well as they had primary or no formal education.

\subsection{Respondents' Views on the Role of Tourism in Reducing Poverty in Kinigi Sector}

The respondents' views on the role that tourism directed towards reducing poverty in Kinigi Sector are enumerated as below.

\subsection{Jobs and Business Opportunities}

The rate of unemployment which is itself is linked to the level of investment be it private or public investment, is a good macro-economic indicator of development in any given country. The Government of Rwanda has made deliberate efforts to provide basic infrastructures to enable and promote tourism related activities in the country in general and in Kinigi sector in particular. The present study aimed was conducted mainly with a view to understanding how local people near the Volcano National Park have benefited tourism in terms of job acquisition and business opportunities. It was found that $18.6 \%$ of the respondents indicated that a numbers had come as a result of tourism, whereas $81.4 \%$ were of the opposite opinion.

\subsection{Tourism Enhancing Local People's Earnings and Savings}

Rwandans in general and villagers in particular used to keep money at their homes before the coming and the now spreading of banking institutions in the country, a practice which did not allow the circulation of money, which, more often than led to the weakening of the economy of the country. Besides, a good number of people in rural areas, earned their income through hand to mouth and therefore, the culture of saving for a better future was unheard or alternatively ignored. Financial institutions have now changed people's perception and tourism in particular have to this change of mindset in Kinigi sector.

The study noted that $28.6 \%$ of the respondents, strongly agreed that tourism has enhanced their earnings and saving, whereas $51.4 \%$ agreed with the same view and only $20 . \%$ did not agree that tourism has enhances people's earnings and savings.

\subsection{Indicators of Improved Living Conditions of the Local People}

Within the context of analysing the effectiveness of tourism in poverty reduction, this study had the specific objective of finding out how much tourism contributing towards the improvement of living conditions of local people near national parks. Some of key indicators of improved living conditions of the communities which came to light included were as noted below.

\subsection{Access to Health Services}

None can deny that good health is a prerequisite pillar to development. In the history of Rwanda, access to health care services had been a big challenge and this had weakened many health indicators such as life expectancy, maternal mortality, infant mortality and child mortality. To overcome this challenge, the Government of Rwanda has introduced the mutual health insurance policy in order to reduce the cost of these services for individual beneficiary. Nonetheless, the cost of individual premium is questionable and this study wanted to explore how many local people in Kinigi Sector can access medical insurance schemes. It was observed that $84.3 \%$ of the respondents had medical insurance whereas only $15.7 \%$ did not have any medical insurance. 


\subsection{Access to Education Services}

An educated population is at the same time the source and a good indicator of sustainable development of any one country around the world. In Rwanda, due to economic and social motives and demands, access to education services especially in rural areas has been a challenge. The researcher wanted to know in which tourism related activities carried out in the area have helped the people of Kinigi Sector to access education services. $73.8 \%$ of the respondents indicated that tourism has helped them to send their children and those of their relatives to school whereas $26.2 \%$ said that access to education services remains a big problem to them. However, it should be understood that tourism alone cannot be considered while evaluating education accessibility issues to people in the area for there are other governmental and non-governmental institutions that play a crucial role on this matter.

\subsection{Food Security}

In the developing world, poverty and hunger are interrelated. One cannot talk about poverty eradication without considering food security since anyone who has not eaten cannot to yield any productive activity. As earlier indicated, the majority of the selected respondents were occupied in the primary sector and the present researcher wanted to know how much this sector affects the local people's food security in Kinigi Sector. It was then observed that $80 \%$ of them said that they are selfreliant on food matters whereas $20 \%$ of them indicated that self- food reliance is far-fetched.

\subsection{Tourism Chanel for Marketing Agricultural Produce}

$85.4 \%$ of the respondents revealed that tourism has helped them to get markets for their agricultural produce and more importantly fruits and vegetables. Only $14.6 \%$ said that they do not easily get markets for their products despite the existence of tourism in the sector. Hence, it can be concluded that tourism does not only provide jobs and business opportunities but it also help local people to get markets for their production.

\subsection{Access to Clean Water}

In the study, access to clean water was also taken as a good indicator measuring the local people's living conditions for it contributes to the reduction of low hygiene related diseases. 'Health is wealth', so they say. For instance, if one is not feeling he can never adequately work and hence, develop him.

It was noted that $77.1 \%$ of the respondents claimed that they have access to clean water whereas only $22.9 \%$ of them said that they did not. Hence, this shows that the policy on revenue sharing has positively impacted the sanitation conditions in Kinigi sector.

\subsection{Source of Cooking Energy}

The source of cooking energy was, too, considered the by the researcher to be a good indicator of living conditions among the rural households, for $94.8 \%$ of the respondents of the study indicated that they use traditional fire woods to prepare their foods whereas $18.6 \%$ t use charcoal or other sources of energy to cook their foods. This then, demonstrates how much environmental protection strategies have been be put forward to protect forests in the area.

\subsection{Type of Lighting System Used}

Another important indicator of the population's living condition is the type of lighting system used during evening hours for this has an impact on children' studies in particular. It was found that $12.9 \%$ use fire woods, $75.7 \%$ use kerosene and whereas $11.4 \%$ use electricity and other means for lighting systems.

\subsection{Possession of Communication Equipments}

In today's world, easy access to information does not only speed up business and development but also is an indicator of poverty relaxed population. In the study all information communication tools could not be covered due to time and economic delimitations. Hence, television, radio and mobile phones were selected for they were considered by the researcher to be information-sensitive communication tools in Rwanda. 
It was established that only five respondents were owning television sets in Kinigi Sector. It was not surprising revelation for it television sets apart from for purchasing them, they also require adequate electrical infrastructures.

It was noted that $78.6 \%$ owned radiophone whereas $21.4 \%$ did not own this device. Radio was found to be most medium through the population get information. $37.1 \%$ of the respondents own mobile cell phones whereas $62.9 \%$ of them did not.

\subsection{Taming of Domestic Animals}

In Rwandan culture, taming of domestic animals in general and cows in particular is viewed as an indicator of social prosperity and the main source of social prestige. Besides, domestic animals, serve as a source of fertilizers which, again, can used for agriculture and related activities. The respondents of the study were observed to tame and own animals such as cows, pigs and goats. As found $22.9 \%$ of the respondents indicated that they did not any cow, $61.4 \%$ said that they owned atleast one cow whereas $15.7 \%$ owned more than three cows. Hence, since the study shows that the majority of households own cows, it can then be said that thisa good indication that the level of poverty in the area is reducing. Again, the study shows that $27 . \%$ of the respondents owned no pig, $64.3 \%$ owned between one to three pig, and $8.9 \%$ owned four or more pigs.

Data for the study also indicate that that $52.9 \%$ of the respondents did not own any goat, $42.9 \%$ owned between one to two goats whereas $4.3 \%$ owned more than four goats. The fact that there are only a few respondents who owned goats can be associated with the climate of Kinigi sector which is extremely cold.

Respondents, too, were asked to explain to what extent tourism has helped them in their day-today life. $25.7 \%$ of them stated that tourism and tourism related activities have helped them to a greater extent, $61.4 \%$ of that it helped them at some extent whereas $12.9 \%$ said that tourism has helped them to a small extent. Therefore, this shows that on average the people of Kinigi Sector recognise and appreciate the role played by tourism and tourism related activities in their life.

\section{Summary OF MaIn FindingS}

The present study covered seventy (70) respondents selected from Kinigi Sector of Musanze District. The purpose of the study was to assess how tourism can be used in alleviating poverty among communities living near the National Volcano Park. The respondents differed from each other in respect to their age, sex, marital status, educational level and occupation which might have also influenced their opinions.

$18.6 \%$ of the respondents noted to have either obtained themselves a job or created a business as result of tourism and tourism related activities. Further, about $28.6 \%$ of them acknowledged that in one way or the other, tourism has improved their earnings and savings.

As regards their living conditions, beneficiaries acknowledged that due to tourism, they now have access to medical services; clean water; educate their children and relatives .Besides, they claim to be self reliant on food production and have sustainable food security. They, too, have ready markets for their produce. The majority of the beneficiaries stated that that are able to access information through the acquired communication tools such as radio, mobile cell phones as a consequence of tourism and tourism related activities taking place in the area.

\section{CONCLUSION}

Globally, it is estimated that a fifth of the world's population lives in extreme poverty. Most of the world's poor live in the developing countries, particularly in the countries of the Sub-Saharan Africa. In order to overcome poverty traps, a number of poverty reduction policies have been put in place by the Government of Rwanda. Indeed, experience has shown that tourism sector accounts a big portion of the Gross Domestic Products (GDP) in a good number of the developing countries in general and Rwanda in particular. However, the major problem is how much do these revenues from tourism affect the lives of local people near national parks? This is a question of great interest to all the concerned stakeholders.

It is against the framework of assessing the effectiveness of tourism on local people near national parks that the present research was conducted. Through findings it can then be concluded that: 
tourism has contributed. to a large extent, towards the improvement of living conditions of the local people in areas near national parks by enabling them to have access to medical and educational services; accessing clean water; enhancing and stimulating their earnings and savings and helps them to get markets for both their agricultural and handcraft products. Hence, through all these opportunities, poverty short backs are reduced.

\section{RECOMMENDATIONS}

The present researcher has made some recommendations to different stakeholders such as policy makers, local people living near the national volcano park and governmental institutions on issues to be addressed for a better performance of tourism sector that can lead to sustainable poverty alleviation in Kinigi Sector as noted below.

Tourism sector can contribute to economic growth by creating new activities and industries which, in turn, can create new employment opportunities and contribute to national economic growth. Hence, based on the findings of the study, if poverty alleviation is to be achieved, the Government of Rwanda should make the tourism sector to be more productive by: Conducting advanced researches to find out other touristic areas in order to increase and diversify revenues from tourism; Find out a way to optimise the number of tourists that enter the country with the amount of revenues they come with. Hence, reducing mass tourism by promoting high class tourists and encouraging Rwandans to participate in tourism activities, too.

The communities residing around the National Parks should cultivate amongst themselves the culture of self reliance through the promotion of entrepreneurship which in the long run will help in alleviating poverty in the area. Hence, the local people around the national parks should be cooperate and protect these touristic areas against burnings and animal killing and also know how to create small scale projects in order to extract more profits from tourism and related activities.

\section{SUGGESTIONS FOR FURTHER RESEARCH}

Based on the findings and experiences gained through the present study, the research suggests that the future researchers and scholars as well, can undertake a study find out "What are the social and economic motives that limit the people of Kinigi Sector in Particular and Rwandans in general in actively participating in tourism activities?"

\section{REFERENCES}

[1] Ashley C, Goodwin H and McNab D,. (2005) Making Tourism Count for the Local Economy in Dominican Republic: Ideas for Good Practice.

[2] Ashley, C., Roe, D. and Goodwin, H., (2001) PPT Report No. 1 Pro-poor tourism strategies: Making tourism work for the poor. A review of experience.

[3] Boo, Elizabeth. (1990). Ecotourism: The Potentials and Pitfalls. Vol 1.

[4] Brohman, J. (1996) New Directions in tourism for third world development. Annals tourism Research 23,1,48-70.

[5] Caroline Ashley (2007) Pro-poor analysis of the Rwandan tourism value chain An emerging picture and some strategic approaches for enhancing poverty impacts

[6] Caroline Ashley, Jonathan Mitchell (2012)Tourism and Poverty Reduction: Pathways to Prosperity

[7] Chok and Macbeth, (2007).Tourism as a tool for poverty alleviation: A critical Analysis of 'ProPoor Tourism' and Implications for Sustainability.

[8] COLE, S. (2006), "Information and Empowerment: The Keys to Achieving Sustainable Tourism", Journal of Sustainable Tourism.

[9] COOPER, C. (2006), "Knowledge Management and Tourism", Annals of Tourism Research.

[10] Dean Carson and Jim Macbeth (2005). Regional Tourism Case Innovation in Regional Tourism.

[11] EADE, D. (1997), Capacity-Building: An Approach to People-Centred Development, Oxford UK and Ireland, Oxfam

[12] Elizabeth Boo (1990) Ecotourism: the potentials and pitfalls, Volume 2.p175 
[13] FRITZ, V., AND MENOCAL, A. R. (2007), "Developmental States in the New Millennium: Concepts and Challenges for a New Aid Agenda", Development Policy Review.

[14] Gerosa, V. (2003). Tourism: a Viable Option for Pro Poor Growth in Africa: Tourism and Poverty. Publication Economic Commission for Africa.

[15] Gupta, S P. (2001). Statistical methods. New Delhi: Educational Publishers.

[16] Harold Goodwin (2001) Responsible Tourism and the Market.

[17] Hussey, J. and Hussey, R. (1997). Business research: A practical guide for undergraduate and postgraduate students. London: Palgrave publishers Ltd.

[18] Jill, H and Roger, H. (1997). Business research: a practical guide for undergraduate and postgraduate students. Palgrave: Basingstoke.

[19] Jonathan Mitchel, Caroline Ashley (2010) Tourism and poverty reduction , Pathways to prosperity.

[20] Lima, S,. Eusebio, C., and partidario, M.R. (2011). Tourism and Poverty alleviation: the role of international development assistance. Lisbon

[21] MacCannell (1976) The Tourist, a new theory of the leisure class.

[22] Meyer, D. (2003).What is Price Tourism? Development policy review volume 21, issue 3.

[23] Meyer, D., Ashley, C. and Poultney, C., 2004 ProPoor Tourism Strategies for Businesses: Creating Linkages. Business Implementation of Pro Poor Tourism: Case Study Briefs No. 1

[24] Mike Robinson \& David Picard (2006) Tourism, Culture and Sustainable Development.

[25] Ministry of trade and industry (2009). Rwanda tourism policy. Kigali-Rwanda

[26] Mtui, E., 2007, Towards initiating and implementing incentives for pro poor tourism in Tanzania, Tourism and development: Agendas for action, SNV Netherlands Development Organisation East \& Southern Africa Region.

[27] Nadkarni, S. (2008). Defining the ICT4D plus pro-poor tourism convergence space synergies for Natural allies for global war on poverty.

[28] National Institute of Statistics of Rwanda (2010/11). Integrated Household Living Conditions Survey, EICV3 Thematic Report, and Youth. Kigali-Rwanda

[29] National Institute of Statistics of Rwanda (2012). 2012 Population and Housing Census: Provisional Results. November 2012, Kigali-Rwanda.

[30] Organisation for Economic Cooperation and Development (OECD, 2005). Paris Declaration on Aid Effectiveness. France

[31] PARTIDARIO, M. R., AND WILSON, L. (2010), "Institutional and Professional CapacityBuilding for SEA",

[32] Pearce, (1991)' Tourism Impact and Community Perception: An Equity-Social Representational Perspective.

[33] Roe, D. \& Urquhart Khanya, P.(2001) Pro-poor Tourism Harnessing the World's Largest Industry for the World's Poor. Prepared for World Summit on Sustainable Development, Johannesburg, 2002.

[34] Roger Sapsford, Victor Jupp (2007) Data Collection and Analysis. Romanow Bruce: Communications \& Capacity Building: Exploring Clues from the Literature for Rural Communities.2006.

[35] ROMANOW, P., AND BRUCE, D. (2006), "Communication and Capacity Building: Exploring Clues from the Literature for Rural Community Development", Journal of Rural and Community Development

[36] SCHILDER, D. (2007), "Growth versus equity: the continuum of pro-poor tourism and neoliberal governance", Current Issues in Tourism,

[37] SNV (2010) Manual on Tourism and Poverty Alleviation. Practical Steps for Destinations.

[38] Stroma Cole (2006) Tourism, Culture and Development.

[39] Takadera, Keiichiro (2004). Hinnkon Kokufuku no Tameno Tuurizumu: Pro-Poor Tourism (Tourism for Poverty Alleviation: Pro-Poor Tourism), Tokyo: Kokon Shoin (in Japanese). 
[40] Tanzania, Tourism and development: Agendas for action, SNV Netherlands Development Organisation East \& Southern Africa Region.

[41] The Government of Rwanda Ministry of Finance and Economic Planning (2007) Economic Development \& Poverty Reduction Strategy 2008 - 2012

[42] The World Bank (2009). Annual Report 2009. The world bank group, Washington DC. USA

[43] TOSUN, C. (2000), "Limits to community participation in the tourism development process in developing countries" Tourism Management

[44] Verena Fritz, Alina Rocha Menocal (2007)Developmental States in the New Millennium: Concepts and Challenges for a New Aid Agenda.(p.532)

[45] Werabe Emmanuel Director of Tourism RDB T\&C The Role of Tourism in Poverty Alleviation in Rwanda

[46] William D. Novelli and Bill D. Novelli (2006). Igniting a Revolution to Reinvent America

[47] William Feighery ( 2002) Community Participation In Tourism Development:

[48] World Trade Organization (2002) International trade statistics. WTO Publications, 154, rue de Lausanne - CH-1211 Geneva 21

[49] World Trade Organization (2004) annual report. WTO Publications, 154, rue de Lausanne - CH1211 Geneva 21

[50] Zhao and Ritchie (2007). Pro-poor Tourism: Who Benefits? Perspectives on Tourism and Poverty Reduction.

\section{ELECTRONIC REFERENCE}

[1] http://www.governorscamp.com/responsible-tourism/responsible-tourism-rwanda consulted on 17th May 2012. 